\title{
The Role of Mathematics on Entrepreneurship
}

\author{
Peranan Matematika terhadap Kewirausahaan
}

\author{
Yakin Niat Telaumbanua \\ IKIP Gunungsitoli \\ telaumbanua.yakin@yahoo.com
}

\begin{abstract}
This research aims to know the role of mathematics on entrepreneurship so that it becomes a provision in doing business. This research is implemented to students of the Mathematics Education Study Program, Faculty of Mathematics and Sciences Education, IKIP Gunungsitoli, semester VII. This research uses purposive sample method. The results of this research are mathematics has a major role in entrepreneurial activities, because: 1) mathematics can foster a strong will in doing business, 2) with mathematics a person is able to make the right decisions in his business. 3) Mathematics has a creative art that someone can use to innovate and create creativity in their business so that it looks interesting. 4) perseverance is a characteristic possessed when learning mathematics which is very much needed in entrepreneurial activities, 5) mathematics contains ethics that can be applied in entrepreneurship, 6) mathematics has an open ended nature that can be applied in businesses such as making changes to strategies and ways of working for success If you doing business, mathematics can read existing business opportunities, so that existing business opportunities are not wasted.
\end{abstract}

Keywords: mathematics, entrepreneur, entrepreneurship

Abstrak

Penelitian ini bertujuan untuk mengetahui peranan matematika terhadap kewirausahaan sehingga menjadi bekal dalam menjalani usaha. Penelitian ini dilaksanakan kepada Mahasiswa Program Studi Pendidikan Matematika Fakultas FPMIPA IKIP Gunungsitoli semester VII. Metode Penelitian ini adalah dengan menggunakan metode sampel purposif (purposif sample). Hasil dari penelitian ini adalah matematika memiliki peranan yang besar terhadap kegiatan kewirausahaan, karena: 1) matematika dapat menumbuhkan kemauan yang kuat dalam menjalankan usaha, 2) dengan matematika seseorang mampu mengambil keputusan yang tepat dalam usahanya. 3) matematika memiliki seni kreatif yang mampu digunakan seseorang untuk berinovasi dan menciptakan kreativitas dalam usahanya sehingga tampak menarik. 4) ketekunan merupakan ciri yang dimiliki ketika belajar matematika yang sangat dibutuhkan dalam kegiatan kewirausahaan, 5) matematika mengandung etika yang dapat diterapkan dalam kewirausahaan, 6) matematika memiliki sifat open ended yang bisa diterapkan dalam usaha seperti melakukan perubahan terhadap strategi dan cara kerja untuk keberhasilan usaha yang dijalankan, matematika bisa membaca peluang usaha yang ada, sehingga peluang usaha yang ada tidak tersia-siakan.

Kata kunci: matematika, wirausaha, kewirausahaan

(*) Corresponding Author: telaumbanua.yakin@yahoo.com

\section{PENDAHULUAN}

Pendidikan merupakan salah satu proses yang dijalani oleh seorang peserta didik untuk mendapatkan pengetahuan serta pembentukan karakter seseorang untuk menjadi manusia yang terampil sesuai dengan tujuan pendidikan, sehingga setelah menyelesaikan pendidikan seseorang dapat menerapkan ilmu pengetahuannya dalam segala aktivitasnya yang dapat menunjang keberlangsungan hidupnya dan bermanfaat bagi orang banyak. 


\section{The Role of Mathematics on Entrepreneurship \\ Yakin Niat Telaumbanua \\ IKIP Gunungsitoli}

Keterampilan seseorang dalam menerapkan ilmu yang telah diperolehnya dari pendidikan salah satunya adalah mampu membaca peluang yang ada dan menciptakan sesuatu dari peluang tersebut. Salah satu bentuk peluang yang bisa dimanfaatkan dan menjadi berharga adalah peluang usaha. Dalam memanfaatkan peluang usaha, sangat dibutuhkan keberanian dan kreativitas dalam memulai usaha tersebut.

Mampu mencari, menciptakan dan membaca peluang usaha disebut dengan usaha. Selanjutnya, kemampuan seseorang dalam merancang dan menjalankan suatu usaha dengan kreatif, inovatif dan berani disebut sebagai kewirausahaan, sedangkan orang yang menjalankan suatu usaha atau kewirausahaan adalah wirausahawan. Menjadi seorang wirausaha merupakan peluang dan alternatif pekerjaan yang bisa dijalani oleh seseorang, terlebih setelah seseorang menyelesaikan pendidikannya. Banyak orang yang telah menyelesaikan pendidikannya menjadi pengangguran dan susah mendapatkan pekerjaan. Cara untuk mengatasi pengangguran tersebut adalah menjadi seorang wirausahawan. Alifah \& Sutirna (2019: 893) mengatakan bahwa wirausaha merupakan salah satu alternatif bagi masyarakat untuk mengatasi masalah pengangguran dan kemiskinan.

Wirausaha jika ditinjau dari segi epistemologi berasal dari kata wira dan usaha. Wira, berarti pejuang, pahlawan, manusia unggul, teladan, berbudi luhur, gagah berani dan berwatak agung dan usaha berarti kegiatan mengerahkan tenaga, pikiran atau badan untuk mencapai sesuatu. Secara terminologis, wirausaha adalah mampu untuk mencari, menciptakan dan memanfaatkan peluang untuk mencapai sesuatu yang diinginkan.

Kewirausahaan adalah kemampuan menjalankan usaha dengan cara-cara kreatif, inovasi dan berani mengambil risiko serta memiliki tujuan dan arah yang jelas. Menurut Drucker (Ananda \& Rafida, 2016:3-4) kewirausahaan merupakan kemampuan dalam menciptakan sesuatu yang baru dan berbeda.

Ananda \& Rafida (2016:3-4) mengatakan bahwa kewirausahaan adalah akronim dari kreatif, energik, wawasan luas, inovatif, rencana bisnis, agresif, ulet, supel, antusias, hemat, asa, antusias, negosiatif. Dari akronim tersebut tampak bahwa kewirausahaan mengajarkan cara-cara berpikir kreatif, inovatif, positif, dan menggerakkan hati nurani untuk lebih proaktif, melakukan perubahan, mendorong keingintahuan, ulet, gigih, berani mengambil risiko untuk melakukan hal-hal yang belum pernah dilakukan akan tetapi akan membawa nilai tambah serta keuntungan yang lebih besar.

Karakteristik wirausahawan menurut Zimmerer dan Scarborough (Ananda \& Rafida, 2016:17-

18) adalah:

1. Memiliki komitmen tinggi terhadap tugasnya.

Artinya memiliki komitmen untuk memajukan usahanya.

2. Mau bertanggung jawab.

Semua yang dilakukan selalu diikuti dengan penuh rasa tanggung jawab dan tidak takut rugi jika dilakukan dengan perhitungan yang matang. Keinginan bertanggung jawab ini erat hubungannya dengan mempertahankan internal of locus yaitu minat kewirausahaan dalam dirinya.

3. Peluang untuk mencapai obsesi.

Seorang wirausahawan mempunyai obsesi untuk mencapai prestasi tinggi dan ini bisa diciptakannya.

4. Toleransi menghadapi risiko kebimbangan dan ketidakpastian.

5. Yakin pada dirinya.

6. Kreatif dan fleksibel.

7. Ingin memperoleh balikan segera.

Mempunyai keinginan yang kuat untuk menggunakan pengetahuan dan pengalaman guna memperbaiki penampilannya.

8. Energik tinggi.

Seorang wirausahawan lebih energik dibandingkan dengan rata-rata orang lain.

9. Motivasi untuk lebih unggul.

Seorang wirausahawan mempunyai motivasi untuk bekerja lebih baik dan lebih unggul dari apa yang sudah dikerjakan. 
10. Berorientasi ke masa depan.

11. Mau belajar dari kegagalan.

Seorang wirausahawan tidak takut gagal, selalu memusatkan perhatiannya pada kesuksesan di masa depan dan menggunakan kegagalan ini sebagai guru berharga.

12. Kemampuan memimpin.

Seorang wirausahawan harus mampu menjadi pemimpin yang baik, memimpin sumber daya manusia yang berbagai macam karakternya dan juga memimpin sumber daya non manusia yang harus dikelola sebaik-baiknya.

Menurut Vernia (2019: 54), kewirausahaan memiliki indikator jiwa kewirausahaan yaitu: adanya kemauan yang kuat, mampu mengambil keputusan yang tepat, kreatif, tekun, etika bisnis, melakukan perubahan, dan menangkap peluang.

Kegiatan wirausaha berkaitan erat dengan matematika. Karakteristik dari matematika yang merupakan cara bernalar, alat memecahkan masalah, matematika yang terstruktur, sistematis dan seni yang kreatif sangat menunjang kegiatan kewirausahaan. Berdasarkan penelitian yang dilakukan oleh Prihaswati \& Astuti (2016:13) kepada mahasiswa Prodi Pendidikan Matematika didapatkan kesimpulan bahwa profil wirausahawan matematika adalah: a) berani menghadapi kegagalan dan senang mengembangkan ide-ide baru dalam berwirausaha untuk menciptakan inovasi baru dalam meningkatkan produksi, b) mencari peluang dalam berwirausaha.

Dalam kewirausahaan dibutuhkan kemampuan membaca peluang usaha, keberanian untuk memulai, kemampuan merencanakan kegiatan usaha, kreativitas dan inovasi dalam menjalankan usaha serta memiliki capaian yang ingin dicapai ke depannya. Untuk mendapatkan keterampilan yang baik dalam kewirausahaan, sangatlah dibutuhkan pengetahuan matematika. Matematika merupakan alat untuk memecahkan masalah yang ada, sarana berpikir logis dan merupakan sarana untuk menarik suatu kesimpulan yang tepat. Matematika dapat memberikan berbagai solusi yang tepat dari masalah yang dihadapi dalam kewirausahaan sehingga seorang wirausahawan dapat menyelesaikan masalah yang dihadapi dengan cara yang tepat. Matematika sebagai sarana berpikir yang logis, memiliki prinsip runtut dan sistematis yang dapat digunakan wirausaha untuk merancang serta melaksanakan usahanya tersebut sehingga usaha yang dijalankan memiliki perencanaan yang baik, tertata dan berjalan dengan baik. Melalui matematika juga seorang wirausahawan dapat mengambil keputusan dengan cepat dan tepat dan berani mengambil risiko karena matematika merupakan sarana penarikan kesimpulan. Oleh karena itu, seseorang yang memiliki pengetahuan matematika sangat mampu dan memiliki peluang yang baik dalam menjalankan suatu usaha.

Matematika merupakan penarikan kesimpulan yang dimulai dari hal-hal yang bersifat umum (deduktif). Wahana (2016:118) mengatakan bahwa matematika merupakan sarana berpikir deduktif berupa proses pengambilan kesimpulan yang didasarkan kepada premis-premis yang kebenarannya telah ditentukan. Selanjutnya, Hasratuddin (2015: 44) mengatakan bahwa kebenaran dari pernyataanpernyataan dalam matematika diterima kebenarannya bila telah dibuktikan secara deduktif (umum).

Matematika memiliki beberapa karakteristik seperti yang diungkapkan oleh Hasratuddin (2015: 41- 49) di antaranya yaitu:

1. Berpola pikir deduktif, artinya cara penarikan kesimpulan dimulai dari kebenaran umum yang telah ditentukan,

2. Konsisten dalam sistem, artinya matematika konsisten dalam makna maupun kebenarannya. Suatu teorema atau suatu definisi harus menggunakan konsep atau istilah yang telah ditetapkan terlebih dahulu,

3. Matematika mempelajari tentang keteraturan (rules), struktur yang terorganisasikan, konsepkonsep matematika tersusun secara hierarkis, terstruktur dan sistematik mulia dari konsep yang paling sederhana sampai pada hal yang lebih kompleks,

4. Matematika sebagai tool (alat) dalam menyelesaikan masalah,

5. Matematika sebagai cara bernalar, karena matematika memuat cara pembuktian yang sahih (valid), aturan yang berlaku umum dan sifat penalaran yang sistematis.

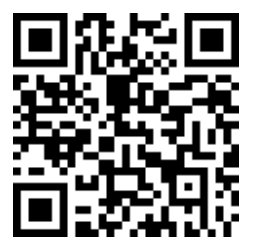

DOI PUBLIKASI https://doi.org/10.37010/int.v2i1 
6. Matematika sebagai seni yang kreatif, karena matematika memiliki penalaran dengan ide-ide yang logis dan pola-pola yang kreatif dan menakjubkan.

\section{METODE}

Penelitian ini dilaksanakan kepada Mahasiswa Program Studi Pendidikan Matematika Fakultas FPMIPA IKIP Gunungsitoli semester VII. Metode Penelitian ini adalah dengan menggunakan metode sampel purposif (purposive sample). Jenis data dalam penelitian ini yaitu data kuantitatif. Data ini diperoleh peneliti berdasarkan hasil angket yang diberikan kepada responden.

Instrumen penelitian ini adalah dengan menggunakan angket. Angket diberikan kepada responden (mahasiswa) untuk diisi yang berisi indikator jiwa kewirausahaan, yang terdiri dari:

1. Dalam belajar matematika dibutuhkan kemauan yang kuat, hal tersebut dibutuhkan juga dalam menjalankan usaha.

2. Matematika mampu mengambil keputusan yang tepat dalam menjalankan usaha seperti perencanaan yang tepat, pelaksanaan rencana dan perhitungan untung/rugi karena pengambilan kesimpulan didasarkan pada cara berpikir deduktif dan menggunakan logika serta penalaran yang tepat.

3. Matematika sebagai seni yang kreatif, karena memiliki penalaran dengan ide-ide yang logis dan pola-pola yang kreatif dan menakjubkan yang sangat dibutuhkan dalam kegiatan wirausaha.

4. Ketekunan dalam berwirausaha merupakan ciri yang sama yang dimiliki ketika belajar matematika, karena matematika sebagai tool (alat) yang kreatif dengan memiliki berbagai cara dan ketepatan dalam menyelesaikan masalah.

5. Matematika mengandung etika karena dalam melakukan sesuatu ada aturan dan langkah yang jelas dan hasilnya pasti tepat sehingga terhindar dari kecurangan, hal tersebut sangat dibutuhkan dalam kewirausahaan.

6. Matematika memiliki sifat open ended yaitu memiliki berbagai cara dalam penyelesaian masalah, hal tersebut sangat dibutuhkan ketika ingin melakukan perubahan strategi atau cara dalam menjalankan usaha.

7. Matematika bisa membaca peluang usaha yang ada karena matematika memiliki cara bernalar yang dapat melakukan pembuktian yang sahih dan berpikir secara deduktif sehingga bisa ditarik kesimpulan untuk menentukan mana yang bisa dijadikan sebagai peluang usaha.

Dalam penelitian ini skala Likert digunakan untuk mengukur sikap dan persepsi masyarakat tentang peranan matematika terhadap kewirausahaan.

Tabel 1. Skala Likert

\begin{tabular}{rccc}
\hline No & Simbol & Keterangan & Skor \\
\hline 1 & SS & Sangat Setuju & 4 \\
2 & S & Setuju & 3 \\
3 & TS & Tidak Setuju & 2 \\
4 & STS & Sangat Tidak Setuju & 1 \\
\hline
\end{tabular}

Sumber: Sukardi (2003:147)

Hasil jawaban responden selanjutnya dianalisis dengan analisis persentase dengan menggunakan rumus:

Keterangan:

$$
\mathrm{P}=\frac{f}{N} X 100 \%
$$

$\mathrm{P}$ : persentase $(\%)$

f : jumlah responden yang menjawab pilihan jawaban SS/S/TS/STS

$\mathrm{N}$ : jumlah keseluruhan responden 
Hasil perhitungan tersebut, dibandingkan dengan kriteria penilaian persentase berikut ini:

Tabel 2. Kriteria Penilaian Persentase

\begin{tabular}{cc}
\hline Persentase & Kriteria \\
\hline $0 \%$ & Tidak ada/ Tak seorang pun \\
$1 \%-24 \%$ & Sebagian Kecil \\
$25 \%-49 \%$ & Kuran dari Setengahnya \\
$50 \%$ & Setengahnya \\
$51 \%-74 \%$ & Lebih dari Setengahnya \\
$75 \%-99 \%$ & Sebagian Besar \\
$100 \%$ & Seluruhnya \\
\hline
\end{tabular}

\section{HASIL DAN PEMBAHASAN}

\section{Hasil}

Penelitian ini dilakukan kepada mahasiswa program studi Pendidikan Matematika semester VII tentang Peranan Matematika terhadap Kewirausahaan melalui angket yang diberikan kepada mahasiswa berupa daftar pernyataan dengan menggunakan skala likert. berikut:

Dari hasil angket tersebut diperoleh respons dari setiap pernyataan yang diberikan seperti

1. Dalam belajar matematika dibutuhkan kemauan yang kuat, hal tersebut dibutuhkan juga dalam menjalankan usaha.

Respons dari pernyataan tersebut, seperti tampak pada gambar 1 berikut.

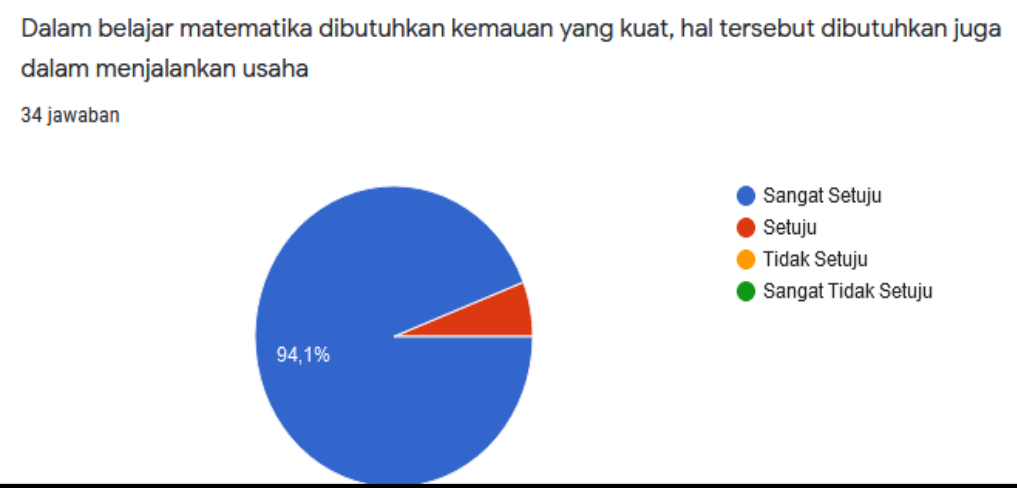

Gambar 1. Hasil respons Pernyataan 1

2. Matematika mampu mengambil keputusan yang tepat dalam menjalankan usaha seperti perencanaan yang tepat, pelaksanaan rencana dan perhitungan untung/rugi karena pengambilan kesimpulan didasarkan pada cara berpikir deduktif dan menggunakan logika serta penalaran yang tepat.

Respons dari pernyataan tersebut, seperti tampak pada gambar 2 berikut. 
Matematika mampu mengambil keputusan yang tepat dalam menjalankan usaha sepert perencanaan yang tepat, pelaksanaan rencana dan perhitungan untung/rugi karena pengambilan kesimpulan didasarkan pada cara berpikir deduktif dan menggunakan logika serta penalaran yang tepat

34 jawaban

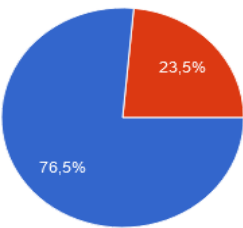

Sangat Setuju

- Setuju

Tidak Setuju

- Sangat Tidak Setuju

Gambar 2. Hasil respons Pernyataan 2

3. Matematika sebagai seni yang kreatif, karena memiliki penalaran dengan ide-ide yang logis dan pola-pola yang kreatif dan menakjubkan yang sangat dibutuhkan dalam kegiatan wirausaha. Respons dari pernyataan tersebut, seperti tampak pada gambar 3 berikut

Matematika sebagai seni yang kreatif, karena memiliki penalaran dengan ide-ide yang logis

dan pola-pola yang kreatif dan menakjubkan yang sangat dibutuhkan dalam kegiatan

wirausaha

34 jawaban

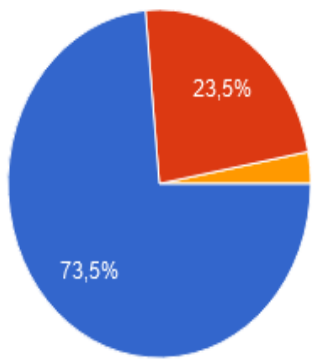

Sangat Setuju

Setuju

Tidak Setuju

Sangat Tidak Setuju

Gambar 3. Hasil respons Pernyataan 3

4. Ketekunan dalam berwirausaha merupakan ciri yang sama yang dimiliki ketika belajar matematika, karena matematika sebagai tool (alat) yang kreatif dengan memiliki berbagai cara dan ketepatan dalam menyelesaikan masalah.

Respons dari pernyataan tersebut, seperti tampak pada gambar 4 berikut 


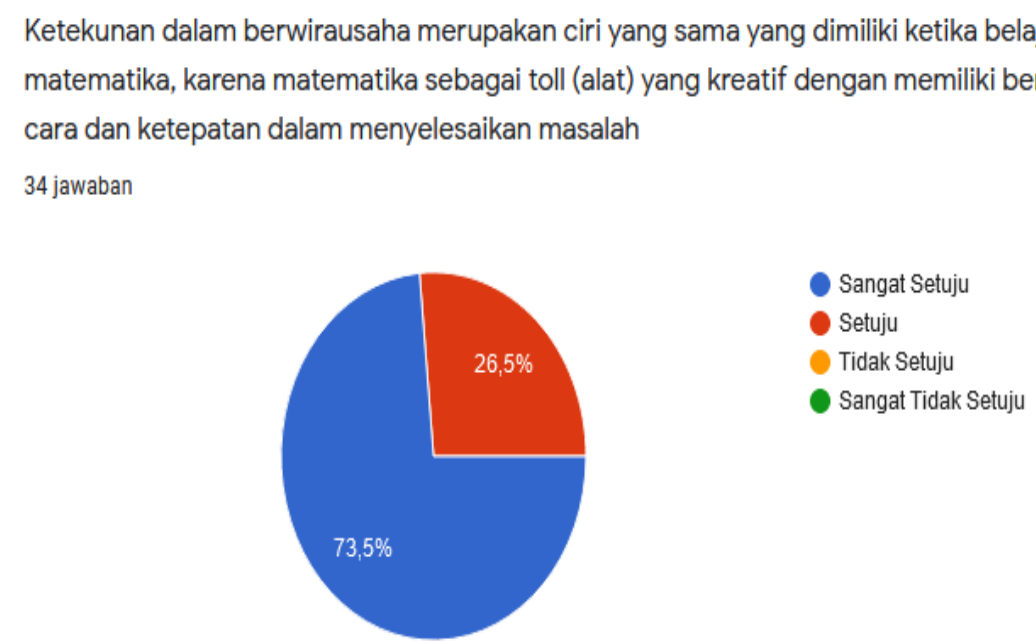

Gambar 4. Hasil respons Pernyataan 4

5. Matematika mengandung etika karena dalam melakukan sesuatu ada aturan dan langkah yang jelas dan hasilnya pasti tepat sehingga terhindar dari kecurangan, hal tersebut sangat dibutuhkan dalam kewirausahaan.

Respons dari pernyataan tersebut, seperti tampak pada gambar 5 berikut

Matematika mengandung etika karena dalam melakukan sesuatu ada aturan dan langkah yang jelas dan hasilnya pasti tepat sehingga terhindar dari kecurangan, hal tersebut sangat dibutuhkan dalam kewirausahaan

34 jawaban

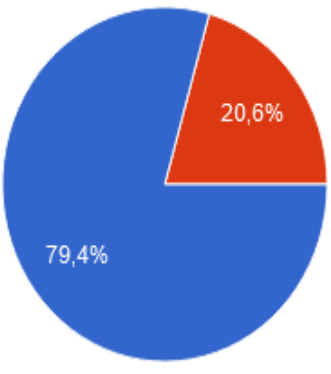

$$
\begin{aligned}
& \text { Sangat Setuju } \\
& \text { Setuju } \\
& \text { Tidak Setuju } \\
& \text { Sangat Tidak Setuju }
\end{aligned}
$$

Gambar 5. Hasil respons Pernyataan 5

6. Matematika memiliki sifat open ended yaitu memiliki berbagai cara dalam penyelesaian masalah, hal tersebut sangat dibutuhkan ketika ingin melakukan perubahan strategi atau cara dalam menjalankan usaha.

Respons dari pernyataan tersebut, seperti tampak pada gambar 6 berikut 
Matematika memiliki sifat open ended yaitu memiliki berbagai cara dalam penyelesaian masalah, hal tersebut sangat dibutuhkan ketika ingin melakukan perubahan strategi atau cara dalam menjalankan usaha

34 jawaban

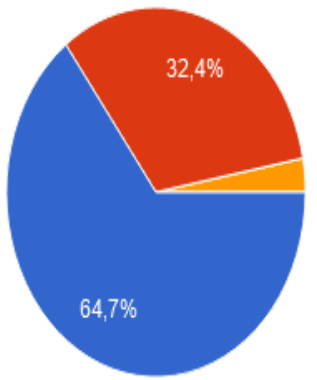

$$
\begin{aligned}
& \text { Sangat Setuju } \\
& \text { - Setuju } \\
& \text { - Tidak Setuju } \\
& \text { - Sangat Tidak Setuju }
\end{aligned}
$$

Gambar 6. Hasil respons Pernyataan 6

7. Matematika bisa membaca peluang usaha yang ada karena matematika memiliki cara bernalar yang dapat melakukan pembuktian yang sahih dan berpikir secara deduktif sehingga bisa ditarik kesimpulan untuk menentukan mana yang bisa dijadikan sebagai peluang usaha. Respons dari pernyataan tersebut, seperti tampak pada gambar 7 berikut

Matematika bisa membaca peluang usaha yang ada karena matematika memiliki cara bernalar yang dapat melakukan pembuktian yang sahih dan berpikir secara deduktif sehingga bisa ditarik kesimpulan untuk menentukan mana yang bisa dijadikan sebagai peluang usaha.

34 jawaban

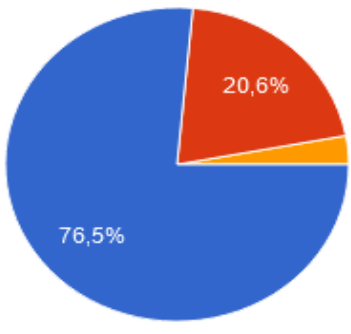

Gambar 7. Hasil respons Pernyataan 7

\section{Pembahasan}

Dari hasil angket yang disampaikan oleh responden, diperoleh bahwa pada pernyataan 1 ada 32 orang atau $94,1 \%$ yang mengatakan sangat setuju terhadap pernyataan 1 . Ada 2 orang atau 5,9\% yang mengatakan setuju. Untuk kategori tidak setuju dan sangat tidak setuju, masing-masing sebesar $0 \%$. Jika dilihat persentase yang paling besar dari jawaban responden yaitu 94,1\% memilih sangat setuju, maka berdasarkan kriteria penilaian persentase, diketahui bahwa "sebagian besar" responden sangat setuju terhadap pernyataan 1, artinya sebagian besar responden sangat setuju bahwa matematika bisa

\section{DOI UNTUK ARTIKEL INI}


membuat seseorang memiliki kemauan yang kuat yang bisa digunakan untuk menjalankan usahanya, sehingga usaha yang dijalankan bisa maju dan sukses.

Pada pernyataan 2 ada 26 orang atau 76,5\% yang mengatakan sangat setuju terhadap pernyataan 2. Ada 8 orang atau $23,5 \%$ yang mengatakan setuju. Untuk kategori tidak setuju dan sangat tidak setuju, masing-masing sebesar $0 \%$. Jika dilihat persentase yang paling besar dari jawaban responden yaitu 76,5 \% memilih sangat setuju, maka berdasarkan kriteria penilaian persentase, diketahui bahwa "sebagian besar" responden sangat setuju terhadap pernyataan 2, artinya sebagian besar responden sangat setuju bahwa dengan matematika seseorang mampu mengambil keputusan yang tepat dalam usahanya.

Pada pernyataan 3 ada 25 orang atau 73,5\% yang mengatakan sangat setuju terhadap pernyataan 3. Ada 8 orang atau $23,5 \%$ yang mengatakan setuju. Ada 1 orang atau 2,9\% yang mengatakan tidak setuju. Untuk kategori sangat tidak setuju sebesar $0 \%$. Jika dilihat persentase yang paling besar dari jawaban responden yaitu 73,5\% memilih sangat setuju, maka berdasarkan kriteria penilaian persentase, diketahui bahwa "lebih dari setengah" responden sangat setuju terhadap pernyataan 3 , artinya lebih dari setengah responden sangat setuju bahwa matematika memiliki seni kreatif yang mampu digunakan seseorang untuk berinovasi dan menciptakan kreativitas dalam usahanya sehingga tampak menarik.

Pada pernyataan 4 ada 25 orang atau 73,5\% yang mengatakan sangat setuju terhadap pernyataan 4. Ada 9 orang atau $26,5 \%$ yang mengatakan setuju. Untuk kategori tidak setuju dan sangat tidak setuju, masing-masing sebesar $0 \%$. Jika dilihat persentase yang paling besar dari jawaban responden yaitu 73,5\% memilih sangat setuju, maka berdasarkan kriteria penilaian persentase, diketahui bahwa "lebih dari setengah" responden sangat setuju terhadap pernyataan 4, artinya lebih dari setengah responden sangat setuju bahwa ketekunan merupakan ciri yang dimiliki ketika belajar matematika yang sangat dibutuhkan dalam kegiatan kewirausahaan.

Pada pernyataan 5 ada 27 orang atau $79,4 \%$ yang mengatakan sangat setuju terhadap pernyataan 5. Ada 7 orang atau $20,6 \%$ yang mengatakan setuju. Untuk kategori tidak setuju dan sangat tidak setuju, masing-masing sebesar $0 \%$. Jika dilihat persentase yang paling besar dari jawaban responden yaitu $79,4 \%$ memilih sangat setuju, maka berdasarkan kriteria penilaian persentase, diketahui bahwa "sebagian besar" responden sangat setuju terhadap pernyataan 5, artinya sebagian besar responden sangat setuju bahwa matematika mengandung etika yang dapat diterapkan dalam kewirausahaan.

Pada pernyataan 6 ada 22 orang atau 64,7\% yang mengatakan sangat setuju terhadap pernyataan 6. Ada 11 orang atau $32,4 \%$ yang mengatakan setuju. Ada 1 orang atau 2,9\% yang mengatakan tidak setuju. Untuk kategori sangat tidak setuju sebesar $0 \%$. Jika dilihat persentase yang paling besar dari jawaban responden yaitu 64,7\% memilih sangat setuju, maka berdasarkan kriteria penilaian persentase, diketahui bahwa "lebih dari setengah" responden sangat setuju terhadap pernyataan 6 , artinya lebih dari setengah responden sangat setuju bahwa matematika memiliki sifat open ended yang bisa diterapkan dalam usaha seperti melakukan perubahan terhadap strategi dan cara kerja untuk keberhasilan usaha yang dijalankan.

Pada pernyataan 7 ada 26 orang atau 76,5\% yang mengatakan sangat setuju terhadap pernyataan 7. Ada 7 orang atau 20,6\% yang mengatakan setuju. Ada 1 orang atau 2,9\% yang mengatakan tidak setuju. Untuk kategori sangat tidak setuju sebesar $0 \%$. Jika dilihat persentase yang paling besar dari jawaban responden yaitu 76,5 \% memilih sangat setuju, maka berdasarkan kriteria penilaian persentase, diketahui bahwa "sebagian besar" responden sangat setuju terhadap pernyataan 7 , artinya sebagian besar responden sangat setuju bahwa matematika bisa membaca peluang usaha yang ada, sehingga peluang usaha yang ada tidak tersia-siakan.

\section{PENUTUP}

Kesimpulan dari penelitian ini adalah matematika memiliki peranan yang besar terhadap kegiatan kewirausahaan, karena: 1) matematika dapat menumbuhkan kemauan yang kuat dalam menjalankan usaha, 2) dengan matematika seseorang mampu mengambil keputusan yang tepat dalam

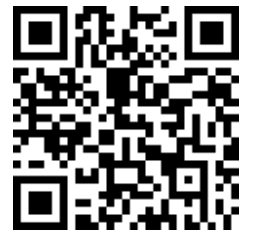

DOI PUBLIKASI https://doi.org/10.37010/int.v2i1 


\section{The Role of Mathematics on Entrepreneurship \\ Yakin Niat Telaumbanua \\ IKIP Gunungsitoli}

usahanya. 3) matematika memiliki seni kreatif yang mampu digunakan seseorang untuk berinovasi dan menciptakan kreativitas dalam usahanya sehingga tampak menarik. 4) ketekunan merupakan ciri yang dimiliki ketika belajar matematika yang sangat dibutuhkan dalam kegiatan kewirausahaan, 5) matematika mengandung etika yang dapat diterapkan dalam kewirausahaan, 6) matematika memiliki sifat open ended yang bisa diterapkan dalam usaha seperti melakukan perubahan terhadap strategi dan cara kerja untuk keberhasilan usaha yang dijalankan, matematika bisa membaca peluang usaha yang ada, sehingga peluang usaha yang ada tidak tersia-siakan.

Melalui penelitian ini, disarankan bagi mahasiswa atau orang yang memiliki kemampuan dalam matematika untuk memanfaatkan ilmunya untuk membaca peluang usaha serta membuka usaha, sehingga bisa tercipta lapangan kerja dan mengurangi pengangguran.

\section{DAFTAR PUSTAKA}

Alifah \& Sutirna (2019). Pembelajaran Matematika Berbasis Wirausaha. Prosiding Seminar Nasional Matematika dan Pendidikan Matematika Sesiomadika 2019. Universitas Singaperbangsa : Karawang.

Ananda \& Rafida. 2016. Pengantar Kewirausahaan. Rekayasa Akademik Melahirkan Enterpreneurship. Perdana Publishing: Medan.

Hasratuddin (2015). Mengapa Harus Belajar Matematika?. Perdana Publishing: Medan.

Prihaswati \& Astuti (2016). Profil Mathematic Teacherpreneur Pada Mahasiswa Pendidikan Matematika. JKPM. Vol. 3, No. 2.

Sukardi (2003). Penelitian Pendidikan. Bumi Aksara : Jakarta.

Vernia (2019). Peranan Pembelajaran Matematika untuk Menumbuhkan Jiwa Berwirausaha Siswa SMK Kota Bekasi. Lectura: Jurnal Pendidikan, Vol.10, No. 1.

Wahana, Paulus (2016). Filsafat Ilmu Pengetahuan. Pustaka Diamond : Yogyakarta. 